\title{
AL-KHULUW (KOMPENSASI PELEPASAN HAK) ANTARA TEORI, PRAKTIK, DAN SOLUSI EKONOMI KONTEMPORER
}

\author{
Oleh: \\ Mustofa \& Manshur Idris \\ Universitas Ibrahimy Situbondo \\ mustofalutfi6@gmail.com \\ haemie3@gmail.com
}

\begin{abstract}
:
Economy continues to grow rapidly especially supported by the advancement of science and technology which increasingly encourages the creation of economic practices that have never happened in the past, the distance between one country and another is getting closer, so it is possible to do transactions between countries both individually and institutionally. In the fields of trade, investment, export-import, stock exchange, leasing, buying and selling, bonds and almost all developing economic practices require answers and legal solutions for Muslims so that their implementation is in accordance with the guidelines of Islamic law, for the sake of the realization of the benefit and goodness of the world and the hereafter. Al-Khuluw (releasing rights) is one of the economic practices developed today in the lease agreement. This practice has developed in several Islamic countries, such as Egypt, Morocco, Iraq and Syria. Al-Khuluw practice is a contract in which the land owner, house or shophouse asks for a sum of money outside the rental price according to the agreement as compensation for him who has rented the place to the tenant or the owner gives money outside the rental price according to the tenant to cancel the contract in the middle the road due to certain reasons, or the first tenant rents his place to the second tenant by accepting money outside the rental price according to the agreement as compensation for the first tenant.
\end{abstract}

Keywords: Al-Khuluw, Kompensasi, Hak

\section{A. Pendahuluan}

Islam adalah agama terakhir yang di turunkan Allah untuk memperbaiki dan meluruskan kembali ajaran-ajaran agama sebelumnya. Islam merupakan agama petunjuk yang mengatur seluruh aspek kehidupan dari yang terkecil hingga yang terbesar. Nabi Muhammad sebagai Nabi terakhir yang membawa ajaran Islam ini telah di beri kitab pedoman al Qur'an sebagai hidayah pembawa manusia dari kegelapan, 
kejumudan, menuju pencerahan, kemajuan, dan menyadarkan kembali tugas kemanusiaan sebagai khalifah Allah di muka bumi1. Umat Islam telah membuktikan dirinya sebagai umat terbaik selalu mengedepankan kemaslahatan umat manusia dengan beramar ma'ruf nahi munkar, di manapun dan sampai kapanpun wajib menyuarakan kebenaran dan menolak kebathilan².

Nabi Muhammad di beri kewenangan oleh Allah untuk menyampaikan, menjelaskan dan menafsirkan ayat-ayat al Qur'an yang turun untuk merespon peristiwa-peristiwa dan kondisi sosial masyarakat muslim ketika itu, bahkan sering kali Nabi memberikan ketentuanketentuan terkait dengan hal-hal atau peristiwa yang tidak secara tekstual di jelaskan ayat-ayat al Qur'an, baik dengan ijtihad, wahyu selain al Qur'an (Hadits Qudsi) maupun pengakuan Nabi atas suatu realita yang terjadi di kalangan kaum muslimin pada saat itu. Segala ucapan, perbuatan, penafsiran dan ketetapan Nabi ini di kenal dengan sebutan al Hadits atau as Sunnah yang merupakan sumber hukum Islam kedua setelah al Qur'an ${ }^{3}$.

Dari sini seorang muslim tentunya menyadari bahwa segala gerak langkah keseharian manusia tidak terlepas dari hukum Islam. Hukum Islam adalah titah Allah yang berhubungan dengan perbuatan orang mukallaf, baik berupa tuntutan, pilihan dan peletakan ${ }^{4}$. Hukum Islam tidak bisa hanya di pahami sebatas aturan ibadah yang merupakan produk istinbath hukum para Mujtahid. Dalam dimensi Ilahiyah, hukum Islam kedudukannya jauh lebih kompleks, ia adalah nilai-nilai ketuhanan dan ajaran suci yang cakupannya meliputi bidang keyakinan (aqidah), prilaku (amaliyah) dan etik moral (akhlaq).

Gejala berkembangnya upaya memahami hukum Islam dalam konteks yang semakin luas telah berjalan sejak awal pertumbuhan Islam, hingga pada zaman modern ini, umat Islam tidak hanya berusaha memahami hukum Islam tetapi juga bagaimana memperoleh pemahaman yang obyektif tentang sejarah hukum Islam untuk dapat memberikan solusi hukum praktis dalam menjawab segala persoalan sesuai konteksnya pada abad global ini ${ }^{5}$.

Hukum Islam tumbuh dan berkembang seiring dengan sejarah

\footnotetext{
1 Departemen Agama RI, al Qur'an dan Terjemahannya, Bandung, CV. Penerbit Diponegoro, 2000, hlm. 3.

2 Ibid, hlm. 50.

3 Muhammad Ujaj al-Khotib, Ushul al Hadits, Bairut, Dar al Fikr, 1409 H/1989 M, hlm. 17. dan Muhammad Abu Zahrah, Ushul al Fiqh, Bairut, Dar al Fikr, tt, hlm. 105

${ }^{4}$ Muhamad Abu Zahrah, Ibid, hlm. 27.

5 Amin Abdullah, Madzhab Jogja, (Yogyakarta, ar Ruz Press, 2002), hlm. 68.
} 
Islam, sejak zaman kenabian, sahabat, tabi'in, pembentukan madzhab dan terus hingga ke zaman modern. Pada masa Rasulullah para sahabat dalam menghadapi suatu peristiwa, dapat langsung menanyakannya kepada Rasulullah. Beliau memberikan jawaban, fatwa dan penjelasan persoalan tersebut berdasarkan wahyu al Qur'an atau dengan Sunnah yang beliau sampaikan baik dengan ucapan, perbuatan atau prilaku Nabi di hadapan para sahabat atau pengakuan Nabi terhadap perbuatan sebagian sahabat, namun cara Nabi yang terakhir ini tetap tidak terlepas dari bimbingan wahyu Ilahi, karena wahyu Allah tidak hanya terbatas pada ayat-ayat al Qur'an saja, tetapi terkadang juga dari Sunnah sesuai firman Allah surat an Najm ayat 3-4 ;

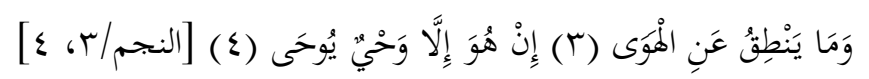

"Dan tiadalah yang diucapkannya itu menurut kemauan hawa nafsunya. Ucapannya tiada lain hanyalah wahyu yang di wahyukan"6

Setelah wafatnya Rasulullah, para sahabat khususnya Khulafa'ur Rasyidin yang menggantikan beliau dalam menangani urusan umat baik berkaitan dengan persoalan keagamaan maupun kenegaraan, dalam memberikan penyelesaian hukum mereka berdasarkan terhadap al Qur'an dan as Sunnah, dan bila tidak menemukan di dalam dua sumber pokok di atas mereka melakukan musyawarah untuk memutuskannya. Namun setelah wilayah Islam semakin meluas dan banyak para sahabat berdomisili di daerah-daerah taklukan, mulailah timbul perbedaaanperbedaan pendapat dalam soal hukum, di sebabkan beberapa faktor, di antaranya sebagian sahabat tidak mengetahui suatu hukum yang pernah di putuskan Nabi di hadapan sahabat lain atau perbedaan ijtihad dalam menjawab dan menyelesaikan persoalan hukum di daerah masing-masing sesuai dengan konteksnya ${ }^{7}$.

Perbedaan ini terus berkelanjutan hingga periode terbentuknya madzhab-madzhab hukum dalam Islam, masing-masing Imam madzhab menggunakan metodenya dalam melakukan Istinbat hukum yang pada kemudian hari populer dengan istilah ilmu Ushul Fiqh setelah di kodifikasi secara sistemik oleh imam Muhammad bin Idris as Syafi'i untuk mendamaikan pertentangan pemikiran yang terjadi antara kalangan rasionalis (Ahlu ar Ro'yi) dan tekstualis (Ahlu al Hadits).

Periode ini adalah periode yang paling aktif dan progresif dalam pembentukan hukum Islam, para imam dan murid-murid terkemuka yang

${ }^{6}$ Departemen Agama RI, al-Qur'an, Op. cit, hlm. 420.

7 Musthofa Said al Khin, Atsar al Ikhtilaf fi al Qawaid al Ushuliyyah Fi al Ikhtilaf al Fuqoha', Bairut, Muassasah al Risalah, 1417 H/1996 M, cet. 6, hlm. 19. 
membangun madzhab hidup dan berkarya dalam rentan waktu abad ke VIII M dan akhir abad ke IX M atau abad ke II dan ke III H. Di antara madzhab yang berkembang pada periode ini dan tetap eksis sampai sekarang adalah madzhab Hanafi (W. 150 H/767 M), madzhab Maliki (W. 179 H/795 M), as Syafi'i (W. 204 H/819 M) dan madzhab Hanbali (W. 241 $\mathrm{H} / 855 \mathrm{M})^{8}$.

Para pendiri madzhab dalam melakukan istinbath hukum menggunakan perangkat metodologi yang di lakukan secara cermat untuk memilah dan membuat ranking berbagai pendapat dan keputusan mereka dari al qur'an dan as sunnah kemudian ijma' dan qiyas (ijtihad), di samping juga menggunakan metode lain yang tidak di terapkan oleh para imam mujtahid lain seperti istihsan, maslahat mursalah, urf, istishab, syar'u man qablana dan qaul sahabi, kemudian metode-metode dan konsep mereka selanjutnya diteruskan dan dikembangkan oleh murid-muridnya ${ }^{9}$.

Pada abad selanjutnya, adalah periode pemberlakuan sistem bermadzhab dalam Islam namun meski demikian kerja-kerja ijtihad tidak pernah berhenti walaupun bukan dalam bentuk ijtihad mutlak, ijtihad yang berkembang pada masa ini adalah para ulama' madzhab menggunakan metode para imamnya untuk merespon persoalan hukum walaupun terkadang kesimpulan hukumnya berbeda dengan imam madzhabnya atau mentarjih salah satu pendapat imam madzhabnya yang di anggap unggul ${ }^{10}$.

Demikian juga ijtihad yang berkembang pada masa modern, segolongan umat Islam, lembaga atau organisasi Islam melakukan istinbath hukum untuk menjawab persoalan hukum kontemporer yang kemudian di tuangkan sebagai fatwa dalam sebuah ketetapan hukum yang di sepakati bersama, ijtihad yang terakhir ini di kenal dengan sebutan ijtihad kolektif (jama'i) ${ }^{11}$.

Seluruh ahli dan pakar hukum Islam sepakat menyatakan bahwa hukum Islam yang berkaitan dengan ibadah dan aqidah telah di jelaskan secara detail dan konkrit dalam al Qur'an dan as Sunnah, hingga terlarang bagi umat Islam membuat bentuk-betuk ibadah yang tidak ada ketentuannya dalam nash, berbeda halnya dalam masalah muamalah,

\footnotetext{
${ }^{8}$ Abdulah Ahmed al- Na'im, Dekonstruksi Syariah, (Yogyakarta, LKIS, 1997), hlm. 33-38.

9 Ibid. hlm. 35.

10 Wahbah al- Zuhaili, al Fiqh al Islamy Wa Adillatuhu, Bairut, Dar al Fikr, cet. IV, i418H/1997 M, juz. 1, hlm. 62-64.

11 Ali Ahmad al salus, al Iqtishad al Islamy, Dauhah, Dar al Tsaqafah, 1418 h/1997 m, juz 1, hlm. 12-13. Abu Yasid, Islam Akomodatif, (Yogyakarta, LKIS, 2004), hlm. 68.
}

$350 \mid$ JURNAL LISAN AL-HAL 
khususnya ekonomi. Nash al Qur'an dan Sunnah hanya menjelaskan secara global dan mengacu pada nilai-nailai prinsip umum yang harus di aplikasikan umat Islam. Hal ini menunjukkan bahwa dalam persoalan muamalah, ijtihad dan perubahan hukum masih terbuka lebar sesuai kondisi perkembangan zaman, tempat dan kemaslahatan, senyampang tidak bertentangan dengan dalil-dalil dan nilai-nilai hukum Islam yang pasti $\left(\right.$ qath'i $^{12}$.

Dalam bidang ekonomi, dari masa kemasa terus berkembang semakin pesat terlebih di dukung kemajuan ilmu pengetahuan dan tekhnologi yang semakin medorong terciptanya praktik-praktik ekonomi yang belum pernah terjadi pada masa lalu, jarak antar satu Negara dengan yang lain semakin dekat, hingga di mungkinkan untuk melakukan transaksi antar Negara baik individu maupun kelembagaan. Dalam bidang perdagangan, investasi, ekspor-impor, bursa efek, sewa (leasing), jual beli, obligasi dan hampir seluruh praktik ekonomi yang berkembang membutuhkan jawaban dan solusi hukum bagi umat Islam agar dalam penerapannya benar-benar sesuai dengan tuntunan hukum Islam, demi terwujudnya kemaslahatan dan kebaikan dunia dan akhirat.

Termasuk di antara praktik ekonomi yang berkembang pada masa ini adalah praktik kompensasi pelepasan hak (al-Khuluw) dalam akad sewa. Praktik ini banyak berkembang di beberapa Negara Islam, seperti Mesir, Maroko, Irak dan Syiria. Praktik al-Khuluw adalah akad di mana pemilik tanah, rumah atau ruko meminta sejumlah uang di luar harga sewa sesuai kesepakatan sebagai kompensasi baginya yang telah menyewakan tempat kepada penyewa atau pemilik memberikan sejumlah uang di luar harga sewa sesuai kesepakatan pada penyewa untuk membatalkan kontraknya di tengah jalan dikarenakan alasan tertentu, atau penyewa pertama menyewakan tempatnya kepada penyewa kedua dengan menerima uang di luar harga sewa sesuai kesepakatan sebagai kompensasi bagi penyewa pertama.

Hal ini yang mendorong para ahli hukum Islam dan para ekonom Islam untuk membahas dan mendiskusikan praktik al-Khuluw ini. DR Wahbah az Zuhaili dalam buku monumentalnya al Fiqh al Islami mencantumkan dengan jelas hasil keputusan para ulama' tentang praktik kompensasi pelepasan hak (al-Khuluw). Ketetapan ini di keluarkan oleh Akademi Fiqh Islam yang di dalamnya beranggotakan para ahli dan pakar hukum Islam dari seluruh dunia pada tahun 1988 untuk menyikapi dan

12 Said Aqil Husin al Munawawar, Al Qur'an Membangun Tradisi Kesalehan Hakiki, Jakarta, Ciputat Press, cet. 1, 2002, hlm. 290. Abu Yasid, Ibid, hlm. 22. 
merespon praktik di atas menurut ketentuan hukum Islam.

Dari uraian di atas penulis tertarik untuk mempelajari dan mengkaji lebih mendalam ketetapan yang di keluarkan Akademi Fiqh Islam tentang praktik Kompensasi Pelepasan Hak (al-Khuluw) dalam bentuk tema "Analisis Atas Ketetapan Akademi Fiqh Islam Oki Tentang Praktik Kompensasi Pelepasan Hak (Al-Khuluw)".

\section{B. Pengertian Kompensasi Pelepasan Hak (al-Khuluw)}

Sebelum membahas secara lebih luas dan mendetail tentang konsep praktik kompensasi pelepasan hak (al-Khuluw), maka di dalam bab ini, penulis ingin menerangkan terlebih dahulu tentang berbagai hal yang berkaitan dengan pengertian dan definisi praktik al-Khuluw tersebut. Kata kompensasi pelepasan hak merupakan istilah yang diterjemahkan dari kata bahasa arab "الخلو".

Kata " الخلو secara etimologi merupakan derivat (masdar) dari kata (lafad) " خلا- يخلو- خلا الإناء مما فيه خلوا" seperti contoh katanya " wadah kosong dari isinya dengan betul-betul kosong", atau dalam contoh lain "خلا البيت من أهله خلوا " artinya "sebuah rumah kosong dari penghuninya dengan betul-betul kosong".

Dengan demikian contoh diatas dapat dijadikan sebagai pijakan oleh para ahli bahasa Arab yang kemudian menyatakan bahwa kata " خلا فرغ- يفرغ- " adalah mempunyai pengertian sinonim dengan kata "يخلو- خلوا yang apabila diterjemahkan ke dalam bahasa Indonesia mempunyai pengertian kosong, lepas, bebas, dan atau bersih. ${ }^{13}$

Sedangkan secara terminologi fiqih (hukum Islam) para Juris Islam (ulama) kontemporer mendifinisikan kata al-Khuluw (praktik kompensasi pelepasan hak) ini ke dalam beberapa definisi yang sesuai dengan pemahaman mereka terhadap praktik al-Khuluw tersebut, namun demikian definisi-definisi yang ditawarkan oleh para juris Islam (ulama) tersebut di dalamnya tidak mengandung perbedaan pendapat terhadap pemahaman tentang praktik kompensasi pelepasan hak (al-Khuluw), bahkan di antara definisi satu dengan definisi lainnya yang telah ditawarkan oleh para juris (ulama) tersebut banyak mengandung

13 al-Fayyumy, Ahmad bin Muhammad, Al-Misbah al-Munir, Bairut, Dar al-Fikr, tt, Juz 1, hlm. 181. Ibrahim Anis dkk, al-Mu'jam al-Wasith, cet. 2, Bairut, Dar al-Fikr, tt, juz 1, hlm. 254. Luis Ma'luf, al-Munjid, Bairut, Dar al-Masyriq, cet. 39, 2002, hlm. 194. A.W. Munawwir, Kamus Munawwir, Surabaya, Pustaka Progresif, 1997, hlm. 366.

$352 \mid$ JURNAL LISAN AL-HAL 
keterkaitan dan persamaan pemahaman yang kesemuanya saling mendukung dan menguatkan antara masing-masing definisi yang mereka berikan.

Definisi-definisi yang telah dibuat oleh para juris Islam (ulama) tentang praktik kompensasi pelepasan hak (al-Khuluw) tersebut, di antaranya adalah menurut :

Pertama, Syekh Muhammad Rowwas Qol'ajy mendefinisikan praktik kompensasi pelepasan hak (al-Khuluw) dengan definisi yang sangat pendek dan ringkas yaitu :

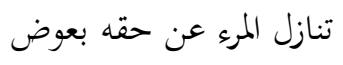

"Melepaskannya seseorang dari haknya dengan mendapatkan ganti rugi (kompensasi)".

Dalam kesempatan yang lain dengan bahasa yang berbeda, beliau mendefinisikan praktik kompensasi pelepasan hak (al-Khuluw) dengan definisi yang cukup panjang dan secara praktis lebih kongkrit, yaitu:

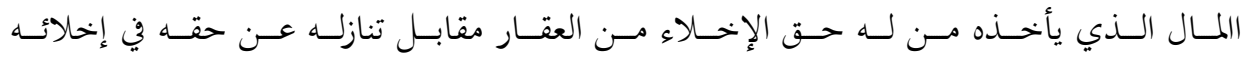

$$
\begin{aligned}
& \text { المستئجر(بكسرالجيم) منه عند إنتهاء مدة الاجارة. }
\end{aligned}
$$

"Sejumlah harta benda yang diambil oleh orang yang mempunyai hak pengosongan tanah pekarangan sebagai imbalan dan kompensasi baginya yang telah melepaskan hak pengosongan tempat dari penyewa ketika masa sewa tanah telah berakhir".

Dan juga beliau menjelaskan praktik ini dalam kesempatan lain dengan ungkapan:

$$
\text { الخلومن الحقوق الاصلية وهي حقوق يصح التنازل عنها مقابل مال. }
$$

"Kompensasi pelepasan hak (al-Khuluw) merupakan hak- hak mendasar yang asal, yaitu hak-hak yang bisa dilepaskan oleh pemiliknya dengan mendapatkan kompensasi sejumlah harta"14.

Definisi yang ditawarkan oleh Syekh Muhammad Rowwas Qol'ajy diatas memberikan penjelasan bahwa pemilik hak pengosongan tanah sewa (pemilik atau penyewa pertama) dapat menggagalkan transaksi (akad) yang telah berlangsung untuk menarik haknya dari penyewa dengan syarat pihak penyewa memberikan sejumlah harta padanya sebagai kompensasi baginya pada akhir masa sewa.

14 Muhammad Ustman Syabir, al- Mu'amalat al-Maliyat al- Mu'ashirah, cet. 1, Yordania, Dar al-Nafa'is, 1996 M/1416 H, hlm. 79.

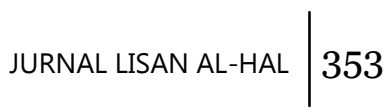


Dr. Wahbah al-Zuhaili menegaskan bahwa definisi kompensasi pelepasan hak (al-Khuluw) adalah:

$$
\text { الإنتفاع به. مـ المال يدفعه الشخص نظير تنازل المنتفع بعقار (أرض أودار أو محل أوحانوت) عن حقه في }
$$

"Sejumlah harta yang diserahkan seseorang sebagai kompensasi terhadap pemilik manfaat tanah pekarangan baik berupa tanah, apartement / perumahan, tempat atau ruko dan pertokoan, karena dia telah melepaskan haknya dalam memanfaatkan tanah sewa"15.

Definisi singkat yang diberikian Dr. Wahbah ini nampaknya lebih jelas dan secara aplikatif lebih kongkrit disamping juga memperkuat terhadap definisi yang dikemukakan pertama dengan lebih transparan atau terbuka menyebutkan obyek-obyek yang dijadikan sasaran dalam praktik kompensasi pelepasan hak (al-Khuluw) yaitu berupa tanah, apartement, perumahan, ruko dan pertokoan yang ada di Negara-negara timur tengah.

Sedangkan dalam kesempatan lain Syekh Masyhur Hasan menyatakan bahwa definisi kompensasi pelepasan hak (al-Khuluw) adalah

$$
\text { تنازل مالك المنفعة عن ملكيته لما مقابل مال زائد عن الأجرة }
$$

"Melepaskannya pemilik manfaat dari hak kepemilikan manfaat sebagai perimbangan dan kompensasi sejumlah harta lebih di luar harga sewa (yang telah dia terima dari pihak penyewa) ${ }^{16}$.

Dari definisi-definisi yang ada di atas dapat ditarik kesimpulan dan persamaan pengertian bahwa praktik kompensasi pelepasan hak (alKhuluw) adalah merupakan praktik ekonomi yang lahir dan berkembang di zaman modern sebagai bentuk kelanjutan dan pengembangan dari akad sewa (Ijarah), di mana pemilik manfaat barang sewaan dengan rela hati memberikan haknya pada orang lain (penyewa) sebagai upaya untuk dapat memanfaatkan hak pemilik baik berupa tanah, perkebunan, tempat, apartement, perumahan, ruko dan pertokoan dengan persyaratan ia harus mendapatkan sejumlah harta atau uang dengan jumlah yang lebih di luar harga sewa tersebut sebagai imbalan atau kompensasi baginya.

\footnotetext{
15 Ibid. hlm. 80.

16 Ibid.
}

$354 \mid$ JURNAL LISAN AL-HAL 


\section{Istilah- Istilah Kompensasi Pelepasan Hak (Al-Khuluw)}

Searah dengan perjalanan sejarah dan waktu praktik kompensasi pelepasan hak ini, maka praktik ini tidak hanya lahir, berkembang dan juga dipraktikkan dalam satu Negara yaitu Mesir (akan penulis jelaskan dalam sub pembahasan sejarah praktik kompensasi pelepasan hak (alKhuluw) dalam bab ini), melainkan juga saat ini telah banyak diadopsi dan diaplikasikan oleh Negara-Negara Islam yang lain, seperti Irak, Maroko, Syiria, dan Arab Saudi.

Negara-negara ini dalam mengaplikasikan praktik kompensasi pelepasan hak (al-Khuluw) terkadang menggunakan istilah-istilah yang berbeda dengan Negara yang pertama kali melahirkan konsep praktik ini walaupun secara substansial dalam tataran aplikatif dan praktisnya tidak mengandung perbedaan. Diantara istilah- istilah yang dipakai Negaranegara tersebut adalah:

Pertama, Al-Suraqfuliyyah ( السرقفلية ): Istilah ini dikenal dan sering digunakan oleh kalangan penduduk Irak, dan kata ini sebetulnya berasal dari bahasa Persia yang mengandung pengertian bahwa pihak penyewa melepaskan barang yang ada dalam kuasanya dalam bentuk dengan menyewakannya kembali pada pihak lain dengan kompensasi mendapatkan sejumlah harta atau uang sesuai kesepakatan yang terjadi antara kedua belah pihak dalam transaksi sewa menyewa (Ijarah). ${ }^{17}$

Kedua. Al- Furugh/al- Furughiyyah (الفروغية /الفروغ): Sebagian penduduk Syiria mengenal praktik kompensasi pelepasan hak (al-Khuluw) ini dengan menggunakan istilah al-Furugh diatas dengan mempertimbangkan persamaan secara etimologis antara kata al-Khuluw dengan kata al-Furugh yang sama- sama mempunyai pengertian lepas, kosong, bersih, dan bebas. ${ }^{18}$

Ketiga, Al- Jalsah (الجلسة): Penduduk Maroko di benua Afrika memakai istilah al-Jalsah ini untuk praktik kompensasi pelepasan hak (alKhuluw) karena berdasarkan pada realitas masyarakat setempat bahwa pihak penyewa dapat "duduk" menguasai tempat yang telah ia sewa dari pemilik hak dengan catatan ia harus memenuhi syarat-syarat yang telah disepakati kedua belah pihak seperti menyerahkan sejumlah harta atau uang kepada pemilik hak. Berpijak dari konteks diatas Imam al- Fasy mendenisikan al-Jalsah (الجلسة) diatas dengan :

17 Ibid.

18 Ibid. 


$$
\text { عقد كراء على شرط متعارف }
$$

"(al-Jalsah) adalah transaksi (akad) sewa menyewa atas berdasarkan syarat- syarat yang dikenal secara umum".

Maksud definisi diatas adalah bahwa pihak penyewa membeli kekuasaan dan bermaksud untuk menempati ruko yang telah disewanya dalam jangka waktu yang lebih lama dengan catatan harus memberikan sejumlah uang kepada pemilik hak sebagai kompensasi baginya dengan jaminan berlangsung terusnya akad sewa yang berkonsekwensi bahwa pemilik tidak boleh mengeluarkan pihak penyewa dari tempat tersebut kecuali atas kerelaannya sendiri atau secara sepihak penyewa telah merusak kemaslahatan akad yang telah disepakati kedua belah pihak.

Hal ini sesuai dengan penjelasan Imam al-Bannany dalam kitabnya Hasyiyah 'Ala Syarhi al-Zarqany bahwa para Ulama Maroko di kota Fes menyebut praktik kompensasi pelepasan hak (al-Khuluw) dalam urusan waqof dengan menggunakan istilah al- Jilsah (الجلسة) 19

Keempat, Al- Miftah ( المفتاح) : Di samping dikenal dengan sebutan alKhuluw, sebagian masyarakat Mesir juga mengenal praktik ini dengan istilah al-Miftah, istilah ini didasarkan pada undang-undang positif yang berlaku di Mesir yaitu undang-undang no. 724 yang mengatur tentang pembatalan segala transaksi yang dilakukan atas nama al-Miftah, karena menurut undang-undang positif Mesir praktik semacam ini termasuk dalam kategori memakan, menguasai dan mengeksploitasi harta orang lain dengan cara batil dan tidak sehat. ${ }^{20}$

Dan diantara sebab-sebab menggeneralkan kata al-Khuluw dengan kata al-Miftah adalah persoalan akad yang dipandang bahwa pemilik manfaat mempunyai otoritas penuh dan peran yang signifikan dalam mentasharrufkan (memamfaatkan) barang yang dimilikinya dan kemudian disewakannya pada pihak penyewa, oleh karenanya sangat tidak logis dan etis secara ekonomis apabila penyewa secara sepihak dapat menguasai barang yang bukan haknya hanya dengan alasan telah memberikan kompensasi sejumlah harta atau uang terhadap pemilik hak tersebut. $^{21}$

Kelima, Al- Zinah (الزينة) : Sebagian penduduk Mesir juga mengenal praktik kompensasi pelepasan hak (al-Khuluw) dengan sebutan al-Zinah di samping nama al-Khuluw dan al-Miftah sebagaimana yang telah dijelaskan

${ }^{19}$ Ibid. hlm. 81.

20 Ibid.

${ }^{21}$ Ibid.

$356 \mid$ JURNAL LISAN AL-HAL 
di atas. Mereka menamakan praktik ini dengan al-Zinah karena mempertimbangkan pada maknanya yang berarti hiasan, dengan pemahaman bahwa dalam praktik kompensasi pelepasan hak (al-Khuluw) pihak penyewa menyandarkan tempat perdagangan yang mereka sewa dengan sejumlah harta atau uang yang jumlah nominalnya telah disepakati kedua belah pihak sebagai hiasan atau dekorasi untuk tetap bisa menempati kembali tempat perdagangan ( ruko) tersebut. ${ }^{22}$

\section{Sejarah Terjadinya Praktik Kompensasi Pelepasan Hak ( Al- Khuluw)}

1. Masa Klasik

Praktik Kompensasi Pelepasan Hak (Al-Khuluw) ini sebenarnya bukanlah merupakan hal yang baru dalam sistem perekonomian umat Islam, dunia Islam pada masa keemasannya pernah menjadi pusat peradaban dunia, kebudayaan, sains, teknologi, termasuk juga dalam bidang ekonomi. Negara Islam pernah menjadi poros perputaran ekonomi dunia baik di belahan Dunia Barat (Eropa) maupun Timur ( Asia).

Para Juris Islam (ulama) yang hidup pada masa itu sangat peduli dalam memperhatikan segala tindak tanduk dan perilaku ekonomi umat Islam agar tidak terjerumus dalam praktik-praktik ekonomi yang diharamkan (dilarang) oleh hukum Islam (Syari'at) yang akan berdampak negatif terhadap kehidupan umat Islam baik secara individu maupun sosial.

Terbukti dengan banyaknya fatwa-fatwa ulama yang tertulis di dalam lembaran-lembaran kitab yang mereka susun atau dalam undangundang pemerintah Islam khususnya dalam bidang fiqh yang mengatur hukum muamalah dan ekonomi yang benar dan sesuai dengan nilai-nilai ajaran Islam yang agung seperti kitab Al-Kharaj yang dikarang Imam Abu Yusuf murid Imam Abu Hanifah dan kitab Al-Muqaddimah yang ditulis Imam Ibnu Kholdun serta kitab-kitab lain karangan para ulama Islam yang telah menjadi acuan pokok pengembangan ekonomi umat Islam dan menjadi bahan kajian penelitian bangsa eropa pada masa-masa berikutnya.

Para ulama dengan dibantu para khalifah dan pakar ekonomi Islam pada masa itu telah terbukti mampu merumuskan secara sistematis tentang tata cara dan etika bisnis yang Islami dengan mengarang kitab fiqh dan membentuk undang-undang jual beli, zakat, ijarah, waqaf, rahn, pertanahan, pengaturan pasar, pertanian, bea cukai, penetapan harga,

22 Ibid. 
pajak dan lain- lainnya. ${ }^{23}$

Adapun praktik kompensasi pelepasan hak (al-Khuluw) pada awal mulanya dikenal dan berkembang pada abad $9 \mathrm{H}$, pada masa ini praktik tersebut merupakan salah satu kegiatan ekonomi yang dilakukan oleh umat Islam sebagai solusi alternatif untuk mengembangkan pengelolaan dan pembinaan tanah wakaf, pertokoan dan perumahan yang dibangun oleh pemerintah yang diserahkan penanganannya pada masyarakat umum bertujuan untuk kemaslahatan ekonomi Negara dan umat Islam. ${ }^{24}$

Beberapa ulama yang hidup pada abad ini telah banyak mengeluarkan fatwa hukum tentang praktik kompensasi pelepasan hak (al-Khuluw) ini, diantaranya adalah Imam Ibnu Abidin pengarang kitab Hasyiyah, Imam Ibnu Najim dengan kitabnya Al-Asybah Wa Al-Nadho'ir, Imam Al-Ulaisy pengarang kitab Minahul Jalil, Imam Syamsuddin Muhammad Bin Hasan Al-Laqqony dan Imam Nashiruddin Muhammad Bin Hasan Al- Laqqony. ${ }^{25}$

Mereka dalam kitab-kitab atau fatwa-fatwanya banyak membahas dan memberikan alternatif hukum tentang praktik kompensasi pelepasan hak (al-Khuluw) juga menjelaskan tentang pentingnya praktik itu dalam berupaya memperbaiki perekonomian umat Islam, terlebih dalam usaha mendorong dan menggerakkan mereka untuk lebih memproduktifkan tanah waqaf, tanah pemerintah, dan pertokoan yang dibuka pemerintah maupun individu agar terhindar dari kerusakan dan terbengkalai karena tidak dikelola dengan baik dan professional.

\section{Masa Modern}

Dalam sejarah peradaban arab modern, Mesir adalah merupakan salah satu Negara Arab yang banyak mempengaruhi terhadap perubahan dan modernisasi di Negara Timur Tengah, Negara ini dihuni oleh bangsa arab yang mayoritas beragama Islam. Modernisasi Negara ini berawal pada tahun 1788-1801 M, Napoleon Bonaparte dari Prancis telah melakukan ekspedisi terhadap Negara ini dan dalam waktu singkat kurang lebih satu bulan dapat menaklukkan beberapa kota penting tanpa adanya perlawanan yang berarti. ${ }^{26}$

23 M. Abdul Mannan, Teori dan Praktik Ekonomi Islam, (Yogyakarta, PT. Dana Bhakti Prima Yasa, 1997), hlm. 23. dan M. Umer Chapra, Masa Depan Ilmu Ekonomi, (Jakarta, Gema Imani Press, 2001), cet. 1, hlm. 201- 202.

24 Op. cit, hlm. 71.

25 Ibid, hlm. 71.

26 Siti Maryam dkk, Sejarah Peradaban Islam, (Yogyakarta, LESFI, cet. 1, 2002), hlm. 352. Lihat Harun Nasution, Pembaharuan Dalam Islam, cet. 12, (Jakarta, Bulan 
Dalam rangka menarik simpati rakyat Mesir khususnya kaum muslimin, Napoleon membuat pamflet berbahasa arab yang mengatakan bahwa orang- orang Mamluk bukanlah pemerintahan muslim yang baik, pamflet ini diawali dengan bacaan Bismillahirrohmanirrohim. Namun usaha Napoleon untuk menguasai daerah-daerah lainnya di Timur Tengah tidak berhasil, sementara perkembangan politik Prancis menghendaki kehadirannya di Paris.

Pada tanggal 18 Agustus $1799 \mathrm{M}$ ia meninggalkan Mesir kembali ke tanah airnya. Ekspedisi yang dibawanya ditinggal di bawah pimpinan Jendral Kleber. Dalam pertempuran melawan Inggris tahun $1801 \mathrm{M}$ kekuatan tentara Prancis di Mesir semakin melemah dan akhirnya mengalami kekalahan sehingga pada tanggal 31 agustus $1801 \mathrm{M}$ ekspedisi ini berakhir dan Napoleon meninggalkan Mesir. ${ }^{27}$

Ekspedisi Prancis yang dipimpin Napoleon ini tidak hanya terdiri dari pasukan tempur tetapi juga diikuti oleh sejumlah sarjana di berbagai bidang ilmu pengetahuan. Kehadiran mereka telah membawa tradisi kebudayaan yang berbeda bagi bangsa Mesir. Napoleon juga membawa dua set alat percetakan dengan huruf latin, arab dan yunani. Dengan demikian kedatangan mereka bukan hanya untuk kepentingan militer tetapi juga untuk kepentingan ilmiah.

Institute D'egypte yang dibentuk Bonaparte mempunyai empat bagian yaitu : bagian ilmu pasti, bagian ilmu kalam, bagian ekonomi politik, dan bagian sastra seni. Perpustakaan institut ini juga banyak berisi buku dalam bahasa Arab, Eropa, Persia, dan Turki. Mereka juga memperkenalkan pada bangsa Arab tentang alat-alat ilmiah seperti teleskop, mikroskop, dan alat-alat riset kimiawi yang membuat bangsa Mesir kagum, tercenung-cenung dan sadar akan ketertinggalan umat Islam selama ini dari bangsa eropa dalam segala bidang. ${ }^{28}$

Pada masa pemerintahan Muhammad Ali Pasya hubungan interaksi antara Mesir dan Eropa semakin erat khususnya dalam bidang ekonomi, perpindahan bangsa asing ke Mesir semakin meningkat, sehingga modal asing muncul di Mesir. Mesir dalam hal ini berpartisipasi besar dalam mempermudah komunikasi dan kerjasama ekonomi antara Dunia Barat

Bintang, 1996), hlm. 29. Hasan Ibrahim Hasan, Sejarah Dan Kebudayaan Islam, Yogyakarta, Kota Kembang, 1989, hlm. 351. Albert Haurani, Sejarah Bangsa- Bangsa Muslim, cet. 1, Terj. Irfan Abu Bakar, Bandung, Mizan, 2004, hlm. 513 - 515. Badri Yatim, Sejarah Peradaban Islam, cet. 6, Jakarta, PT. Raja Grafindo Persada, 1997, hlm. 181- 182.

27 Siti Maryam dkk, Ibid, hlm. 353 - 354. dan Harun nasution, Ibid, hlm. 30

28 Ibid. 
dan Dunia Timur dengan menghidupkan kembali jalan melalui daratan selama pertengahan awal abad ke-19 M.29

Sampai pada abad $20 \mathrm{M}$ hubungan masyarakat yang berkebangsaan Mesir dengan bangsa Eropa terus semakin erat dan terus berlanjut setelah memasuki abad $21 \mathrm{M}$ yang dikenal dengan abad millenium, pada periode ini, interaksi masyarakat Mesir khususnya dengan bangsa Prancis berkembang meliputi berbagai macam bidang kerjasama separti pendidikan, politik, seni, budaya, dan ekonomi. Ini terbukti banyaknya pemuda-pemuda Mesir melanjutkan studinya ke negara Prancis, bahkan tidak sedikit yang menetap dan meniti karir di sana, mereka banyak mempelajari berbagai macam ilmu yang berkembang di Prancis seperti ilmu hukum, militer, ekonomi, tekhnologi, filsafat dan lainnya. ${ }^{30}$

Disamping itu banyak sarjana-sarjana Barat yang ahli dalam bidangnya semakin banyak berdatangan kenegara-negara Timur Tengah terlebih Mesir, mereka memperkenalkan dan mengajarkan ilmu yang mereka kuasai kepada masyarakat setempat khususnya para pemuda yang haus ilmu pengetahuan modern. Dalam bidang ekonomi banyak konsep, sistem dan praktik ekonomi bangsa Barat yang mereka pelajari dan kemudian diadopsi untuk kemudian diaplikasikan di Negaranya, dan selanjutnya secara perlahan namun pasti bangsa-bangsa Arab mengikuti seluruh sistem yang mereka dapatkan dari bangsa Barat baik dalam bidang ekonomi makro maupun mikro, perbankan, dan non perbankan. ${ }^{31}$

Hal ini membuat para ulama resah dan mendorong keseriusan mereka untuk meneliti dan mengkaji secara mendalam seluruh tingkah laku masyarakat Islam terlebih perilaku ekonomi mereka sehari-hari. Para ulama sebagai pewaris nabi tidak ingin umat Islam terjerumus dalam larangan-larangan agama dengan menghalalkan segala cara, bertindak dzolim terhadap sesama hanya karena ingin mendapatkan harta duniawi yang fana dan mengorbankan kepentingan akhirat yang lebih kekal dan abadi. Na'udzu billah.

Seringkali para ulama baik secara individu maupun kolektif dalam bentuk organisasi tertentu mengeluarkan fatwa-fatwa tentang kebolehan dan keharaman praktik ekonomi yang berkembang di masyarakat Islam demi untuk menjaga mereka agar tetap berjalan dalam koridor Syariah Islam.

${ }^{29}$ Albert Hauroni, Sejarah, Op cit. hlm. 526- 527. Badri Yatim, Sejarah, Op cit, hlm. 182. Hasan Ibrahim Hasan, Sejarah, Op cit, hlm. 359.

${ }^{30}$ Siti Maryam dkk, Ibid, hlm. 357. Hasan Ibrahim Hasan, Ibid, hlm. 388.

31 Siti Maryam dkk, Ibid, hlm. 356 .

$360 \mid$ JURNAL LISAN AL-HAL 
Diantara lembaga-lembaga keIslaman yang konsisten dalam merespon segala perilaku umat Islam dengan memberikan jawaban altenatif dalam bentuk fatwa dan ketetapan hukum yang kemudian disebarluaskan kenegara-negara Islam adalah Majma' al-Buhuts alIslamiyah dibawah universitas al-Azhar Kairo Mesir, Majma' al-Fiqh alIslamy di bawah RAI (Rabithah al-Alam al-Islamy), dan Majma' al-Fiqh alIslamy OKI (Organisasi Konferensi Islam) yang hasil ketetapannya tentang kompensasi pelepasan hak (al-Khuluw) menjadi bahan kajian dan penelitian penulis. ${ }^{32}$ Begitu juga banyak lembaga-lembaga lain yang berdiri di negara-negara Islam lainnya seperti MUI, Lajnah Bahtsul Masa'il NU dan Majlis Tarjih Muhammadiyah di Indonesia.

Sebagaimana dijelaskan diatas bahwa para ulama melalui Akademi Fikih Islam (Majma' al-Fiqh al-Islamy) OKI telah mengeluarkan fatwa tentang praktik Kompensasi Pelepasan Hak (al-Khuluw) pada muktamar ke-4 tahun 1408 H/ 1998 M di Jeddah. Persoalan ini telah disinggung sebelumnya bahwa pada awalnya praktik ini telah dikenal umat Islam sejak sekitar abad $9 \mathrm{H}$, praktik ini pada saat itu hanya berkisar pada persoalan produktifitas tanah wakaf, pengembangan tanah dan pertokoan pemerintah yang dikelola masyarakat.

Adapun pada masa modern praktik Kompensasi Pelepasan Hak (alKhuluw) ini mulai kembali dikenal oleh umat Islam pada awal abad $20 \mathrm{M}$ yang diperkenalkan oleh sarjana-sarjana ekonomi dari barat dengan nama Bil-Mizah (بالميزة) yaitu semacam surat yang dituliskan untuk pedagang karena telah mendapatkan tempat perdagangan, kemudian sebutan tersebut diganti dengan nama " harga tempat " ( القيمة المكانية ) dan pada akhirnya kemudian sekitar tahun 1904 M diganti lagi dan lebih dikenal dengan sebutan Badal al-Khuluw, nama ini diperkenalkan oleh Prof. Thaller dalam bukunya Syarh al-Qonun al-Tijary, sejak itu nama Badal AlKhuluw atau disingkat Al-Khuluw menjadi nama baku bagi praktik kompensasi pelepasan hak di timur tengah khususnya di Mesir. ${ }^{33}$

Dalam realitasnya praktik kompensasi pelepasan hak (al-Khuluw ) ini pada awalnya hanya berlaku dan dipraktikkan di Mesir berdasarkan undang-undang militer Mesir nomor 151 tahun $1941 \mathrm{M}$ yang mengatur larangan pemilik (tanah, ruko, rumah) untuk menyewakan miliknya yang telah dikhuluwkan baik berupa tanah, ruko, dan rumah kecuali dengan perantara tuntutan-tuntutan sebagai permohonan yang diajukan dari

${ }^{32}$ Al- Salus, al-Iqtishad, Op. cit, juz. I, hlm. 12-13.

33 Syabir, al-Mu'amalah, Op cit, hlm. 82. 
pihak penyewa.

Kemudian setelah itu hakim militer Mesir mengeluarkan semacam instruksi dan aturan terkait praktik kompensasi pelepasan hak (alKhuluw) diantaranya ketetapan bahwa penyewa pertama yang berkeinginan mengosongkan tempat yang ia sewa boleh memberikan informasi dan mengumumkan kepada penyewa lain tentang keinginannya tersebut, demikian dia juga dapat mematok sejumlah harga diluar harga sewa sebagai kompensasi baginya karena telah mengosongkan tempatnya dengan tujuan agar penyewa lain yang tertarik menyewa tempat tersebut segera mendaftarkan diri sebelum didahului penyewa lain untuk memperoleh tempat itu. ${ }^{34}$

Kemudian selanjutnya praktik ini tidak hanya dilakukan kalangan militer Mesir tapi juga dipraktikkan masyarakat sipil Mesir dan terus mereka perkenalkan ke Negara-negara timur tengah yang lain dengan mengadopsi undang-undang barat yang mengatur praktik kompensasi pelepasan hak (al-Khuluw) ini.

Dari penjelasan-penjelasan ini secara umum dapat ditarik kesimpulan bahwa setidaknya ada beberapa faktor penyebab terjadinya praktik kompensasi pelepasan hak (al-Khuluw) yang mendorong dan menarik umat Islam untuk mempraktikkannya di masa modern, diantara faktor-faktor tersebut adalah :

a. Kemasyhuran dan opini umum yang positif serta banyaknya para pelanggan dan konsumen yang berdatangan ditempat itu.

b. Realitas harga tanah yang berlaku di pasar terkait dengan fluktuasi kenaikan harga tanah juga sangat berpengaruh terhadap penetapan harga kompensasi pelepasan hak (al-Khuluw).

c. Adanya undang-undang pemerintah yang memberikan hak pada penyewa untuk tetap dapat menempati tempat yang telah ia sewa disamping membekukan harga sewa.

d. Kebiasaan (urf) masyarakat melakukan praktik kompensasi pelepasan hak (al-Khuluw) yang disebabkan kebutuhan pemilik pada harta untuk membiayai pembangunan tanah pekarangan miliknya dengan cara mengajukan harga diluar harga sewa kepada pihak-pihak yang tertarik menyewa tempat atau tanahnya dengan maksud agar pemilik dapat membangun tempatnya menjadi lebih baik dan lebih memuaskan penyewa. ${ }^{35}$

34 Ibid, hlm. 82.

35 Ibid, hlm. 82.

$362 \mid$ JURNAL LISAN AL-HAL 


\section{E. Ketetapan Hukum Akademi Fikih Islam tentang Praktik Kompensasi Pelepasan Hak (Al-Khuluw)}

Berpijak pada ketentuan ajaran Islam bahwa setiap perilaku manusia sebagai makhluk sosial terkait hubungannya dengan Allah, sesama manusia dan alam semesta tidak bisa terlepas dari aturan-aturan sang maha pencipta berupa hukum-hukum syariat yang mengatur seluruh aspek kehidupan manusia sebagai khalifah Allah SWT. dimuka bumi. ${ }^{36}$ Maka, Melihat praktik tersebut semakin berkembang dan diminati umat Islam di negara-negara Timur Tengah, para ulama tertuntut untuk merespons segala perilaku umat Islam termasuk praktik ekonominya agar tidak lepas dan keluar dari rel ajaran Islam yang suci.

Bentuk tanggung jawab para ulama tersebut diantaranya adalah dengan memberikan fatwa secara individu maupun kolektif tentang segala hal yang terjadi dikalangan kaum muslimin termasuk diantaranya ketetapan kolektif berdasarkan Ijtihad Jama'i yang diputuskan Akademi Fikih Islam (Majma' al-Fiqh al-Islamy) OKI tentang Praktik Kompensasi Pelepasan Hak (al-Khuluw) pada muktamar yang ke-4 tahun $1408 \mathrm{H} /$ 1988 M bertujuan untuk memberikan solusi hukum berdasarkan Syariat Islam terkait kebiasaan umat Islam di Negara-negara timur tengah melakukan praktik tersebut.

Setelah melakukan dialog dan diskusi yang cukup panjang dengan meneliti dan mengkaji secara mendalam realitas masyarakat Islam di Negara-negara Islam khususnya di Timur tengah seperti Mesir, Irak, Syiria, dan Maroko begitu juga Negara-negara yang lain terkait perilaku mereka dalam menerapkan praktik kompensasi pelepasan hak (al-Khuluw) serta relevansi praktik ini dengan dalil-dalil syar'i dan memandang kemaslahatan yang merupakan tujuan pokok ajaran Islam yang paling mendasar, maka para ulama mengeluarkan ketetapan hukum tentang praktik ini, sebagai berikut:

\section{Ketetapan No. 6 Tentang Praktik Kompensasi Pelepasan Hak (Badal al-Khuluw/al-Khuluw)}

"Sesungguhnya Majlis Akademi Fikih Islam (Majma' Al- Fiqh AlIslamy) pada muktamar ke. IV di Jeddah, Kerajaan Saudi Arabia, tanggal 18-23 Jumadil Akhirah 1408 H/ 6-11 februari 1988 M.

Setelah mempelajari beberapa pembahasan fikih yang masuk pada Akademi Fikih Islam, khususnya mengenai pembahasan praktik

${ }^{36}$ Abdul Wahab Khollaf, Ilmu Ushul al- Fiqh, cet. 12, Beirut, Dar al- Qalam, 1398 H/1976 M, hlm. 11. 
Kompensasi Pelapasan Hak (al-Khuluw), dan dengan berdasarkan pertimbangan diatas menetapkan keputusan sebagai berikut:

Pertama, Bentuk-bentuk kesepakatan yang terjadi dalam praktik kompensasi pelepasan hak (al-Khuluw) terbagi dalam 4 bentuk: 1) Kesepakatan antara pemilik tanah (pekarangan) dan penyewa pada waktu permulaan transaksi (akad); 2) Kesepakatan antara penyewa dan pemilik dipertengahan masa sewa atau setelah berakhirnya masa sewa; 3) Kesepakatan antara penyewa pertama dan penyewa baru dipertengahan masa sewa atau setelah berakhirnya masa sewa; dan 4) Kesepakatan antara penyewa baru, pemilik, dan penyewa pertama sebelum berakhir masa sewa atau setelah berakhir masa sewa.

Kedua, Apabila terjadi kesepakatan antara pemilik dan penyewa agar penyewa menyerahkan sejumlah uang lebih dari harga sewa kepada pemilik, maka menurut pertimbangan hukum syara' pemberian sejumlah uang tersebut tidak perlu ditolak dengan syarat uang tersebut diperhitungkan termasuk dalam harga sewa sesuai ketentuan waktu yang telah disepakati bersama, dan jika terjadi pembatalan maka uang tersebut diperhitungkan secara hukum sebagai harga sewa ( أحكام الأجرة ).

Ketiga, Apabila terjadi kesepakatan antara pemilik dan penyewa dipertengahan masa sewa, bahwa pemilik harus menyerahkan sejumlah uang kepada penyewa sebagai kompensasi karena penyewa bersedia melepaskan haknya untuk memanfaatkan tempat sewa dalam waktu yang masih tersisa yang ia jual kepada pemilik. Sedangkan jika masa sewa telah berakhir dan tidak berlanjut dengan proses transaksi baru antara pemilik dan penyewa baik secara eksplisit ataupun implisit, maka praktik ini dianggap tidak halal, karena pada saat itu pemilik lebih berhak terhadap harta yang ia miliki setelah berakhirnya hak penyewa.

Keempat, Apabila penyewa pertama melakukan kesepakatan dengan penyewa baru dipertengahan proses sewa untuk melepaskan sisa masa sewanya dengan mendapatkan sejumlah uang lebih di luar harga sewa, maka praktik semacam ini diperbolehkan dalam Islam (syara') selama masih tetap menjaga ketentuan-ketentuan akad sewa yang pernah terjadi antara pemilik dengan penyewa pertama serta memelihara undang-undang syari'ah yang berlaku.

Transaksi ini biasanya terjadi pada akad sewa dalam tempo yang lama, berbeda halnya dengan akad sewa yang diatur dalam sebagian undang-undang positif, bahwa penyewa pertama tidak boleh mengadakan akad sewa dengan penyewa baru juga tidak boleh menerima al-Khuluw kecuali dengan persetujuan pemilik

$364 \mid$ JURNAL LISAN AL-HAL 
Sedangkan apabila kesepakatan transaksi antara penyewa pertama dengan penyewa baru ini terjadi setelah masa sewa berakhir, maka tidak halal bagi penyewa tersebut menerima al-Khuluw karena hak penyewa terhadap barang yang disewanya telah habis dan berakhir masanya."37

Ketetapan diatas adalah keputusan hukum yang dihasilkan para ulama kontemporer melalui akademi fikih Islam OKI dalam bentuk fatwa secara kolektif untuk merespon praktik kompensasi pelepasan hak (alKhuluw) yang berkembang luas dalam lingkungan umat Islam modern, didalam ketetapan ini disebutkan secara lugas dan gamblang berbagai macam bentuk praktik kompensasi pelepasan hak (al-Khuluw) beserta hukum-hukum yang terkait dengan praktik ini meliputi praktik kompensasi pelepasan hak (al-Khuluw) yang boleh dilakukan secara syar'i dan praktik yang diharamkan karena mengandung kemudlaratan dan merugikan terhadap salah satu pihak yang terkait dalam praktik ini.

\section{F. Analisa Pendapat Fuqoha' Tentang Praktik (Al-Khuluw) Kompensasi Pelepasan Hak}

Sebagaimana telah dipaparkan secara detail tentang sejarah praktik kompensasi pelepasan hak (al-Khuluw) yang berawal sekitar abad 9 H/15 M. Praktik ini dilakukan umat Islam dalam persoalan wakaf pada saat itu. Dalam usaha semakin mendorong umat Islam memproduktifkan dan memakmurkan tanah wakaf, maka sebagian umat Islam mempunyai inisiatif untuk membuat semacam langkah ekonomis menyewakan tanah wakaf pada pihak yang berminat dengan menetapkan harga diluar harga sewa, dengan kompensasi mendapat sebagian manfaat tanah wakaf yang disewakan.

Kemudian praktik ini juga berkembang pada kasus-kasus lain seperti penyewa menyerahkan sejumlah uang diluar harga sewa pada pewakaf/pengurus, agar dapat lebih lama menempati tempat (ruko) yang disewanya, dan pewakaf/pengurus tidak lagi punya hak mengeluarkan penyewa dari tempat itu.

Demikian juga termasuk praktik kompensasi pelepasan hak (alKhuluw) adalah persoalan status tanah pemerintah yang disewakan kepada penduduk setempat, ditanami, dibangun mereka dengan membayar semacam pajak kepada Baitul mal.

Pada masa modern, praktik kompensasi pelepasan hak (al-Khuluw) tidak hanya dikenal kaum muslimin terbatas dalam persoalan sewa tanah

37 Syabir, al-Mu'malah, Op cit, hlm. 89. lihat juga al-Zuhaily, al-Fiqh al-Islamy, Op. cit, juz. VII, hlm. 5138. Dan al-Salus, al-Iqtishad, Op cit, juz. II, hlm. 786. 
wakaf, tapi juga di praktikkan pada persewaan hak milik pribadi yang meliputi tanah, perumahan, dan pertokoan, semisal pemilik tanah mengambil sejumlah uang diluar harga sewa dari penyewa dengan disandarkan pada standar harga bulanan atau tahunan, atau penyewa mengambil sejumlah uang dari pemilik sebagai kompensasi pengosongan tempat sesuai keinginan pemilik, atau penyewa pertama mematok sejumlah uang pada penyewa lain yang berminat untuk menempati tempat tersebut.

Selanjutnya dari masing-masing contoh praktik kompensasi pelepasan hak (al-Khuluw) yang berlaku pada masa modern ini, ada beberapa pembagian yang menjadi faktor terjadinya praktik tersebut, dan masing-masing membutuhkan ketentuan hukum menurut syari'at Islam sesuai dengan konteksnya.

Maka dari itu, berpijak dari realitas prilaku ekonomi umat Islam klasik maupun kontemporer, terlebih dalam persoalan praktik kompensasi pelepasan hak (al-Khuluw), para ulama klasik maupun kontemporer terdorong untuk memberikan solusi dan alternatif hukum dalam merespon praktik tersebut, dengan tujuan agar umat Islam tidak terjerumus dalam praktik-praktik yang dilarang agama, dzolim, dan hanya mementingkan kepentingan pribadi.

\section{Pendapat Ulama Klasik}

Dari ketiga pengertian al-Khuluw, setidaknya para ulama klasik menggunakan beberapa perangkat sebagai pijakan metodologis untuk menggali hukum dan memberikan solusi yuridis praktis terkait praktik kompensasi pelepasan hak (al-Khuluw).

Pertama, kebiasaan (urf) yang berlaku secara umum pada masyarakat muslim. Menurut ulama ushul, urf bisa menjadi sumber hukum untuk menjawab persoalan yang tidak pernah tersentuh oleh teks al-Qur'an dan sunnah. Dengan catatan, urf tersebut adalah kebiasaan yang dikenal baik dan tidak bertentangan dengan dua sumber hukum yang utama, kebiasaan semacam ini dalam ushul fiqh disebut dengan urf shahih.

Berbeda halnya dengan kebiasaan masyarakat yang mengandung unsur-unsur negatif dan kontradiksi dengan nash-nash syar'i, maka kebiasaan ini dikategorikan urf fasid, dan tidak bisa menjadi pijakan hukum.

Dalam praktiknya, al-Khuluw termasuk dalam kategori urf shahih dengan mempertimbangkan bahwa praktik ini tidak hanya menjadi kebiasaan masyarakat umum, bahkan juga banyak dilakukan oleh kalangan elit masyarakat muslim pada saat itu seperti para ulama, hakim, 
mufti, dan para dosen perguruan tinggi Islam.

Disamping itu, praktik ini telah cukup lama menjadi tradisi umat Islam, dan jika dibatalkan akan berdampak terjadinya krisisis ekonomi disebabkan banyak harta umat yang terbengkalai dan sia-sia. Dan hal ini sangat dilarang dalam hukum Islam yang sangat memperhatikan kemaslahatan umum.

Kedua, analogi (qiyas) terhadap kebolehan ba'i al-wafa' yang biasa dilakukan ulama muta'akhir sebagai rekayasa (hilah) dari riba. Ba'i alwafa' adalah jual beli yang dilangsungkan dua pihak yang dibarengi dengan syarat bahwa barang yang dijual itu dapat dibeli kembali oleh penjual, apabila tenggang waktu yang ditentukan telah tiba. Adapun illat kesamaan antara dua praktik diatas adalah antara pembeli dan penyewa sama-sama dapat memanfaatkan obyek akad (tempat) sebagai kompensasi dari uang yang telah diserahkan.

Ketiga, men-takhrij masalah kompensasi pelepasan hak (alKhuluw) ini dengan dasar kaidah fikih : "sesuatu jika sempit, maka menjadi meluas",dan kaidah : "kesulitan bisa menarik kemudahan". Menurut para ulama, kebanyakan persoalan Ijma' dan Istihsan dalam wacana hukum Islam seringkali didasarkan pada dua kaidah diatas, terlebih pada kasuskasus yang hukumnya tidak ada penegasan yang jelas dari nash-nash syara'.

Keempat, darurat dan memelihara kemaslahatan (الضرورة ورعايـة yaitu menurut para ulama bahwa unsur manipulatif (gharar) yang ada dalam praktik ini masih tergolong rendah dan dapat ditolerir, seperti dampak negatif kemungkinan naiknya harga pasar dan biaya sewa pada waktu itu.

Sedangkan memelihara kemaslahatan disini adalah sesungguhnya orang yang memiliki hak kompensasi pelepasan hak (al-Khuluw) ini posisinya sama seperti pengurus wakaf yang harus mengurusi, merawat dan memelihara wakaf sebaik-baiknya, disamping mendapat bagian dari manfaat wakaf tersebut ${ }^{38}$.

\section{Pendapat Ulama Kontemporer}

Sedangkan respon ulama kontemporer khususnya yang terkumpul dalam akademi fikih Islam dan terlibat langsung dalam muktamar fikih internasional, mendasarkan status hukum praktik al-Khuluw modern atas beberapa argumentasi, diantaranya :

Pertama, fatwa ulama klasik seperti Imam Ulaisy yang menyatakan

38 ibid 
bahwa Praktik kompensasi pelepasan hak (al-Khuluw) tidak hanya berlaku pada persewaan tanah wakaf, bahkan lebih utama bila dihubungkan dengan hak milik pribadi, karena pemilik pribadi punya hak penuh dan lebih kuasa untuk mempergunakan hak miliknya.

Barangkat dari asumsi diatas, para ulama kontemporer memasukkan beberapa praktik kompensasi pelepasan hak (al-Khuluw) modern dalam praktik klasik, seperti kasus pemilik tanah yang membutuhkan biaya untuk mempebaiki tanahnya, penyewa mengambil sejumlah uang diluar harga sewa dari pemilik sebagai kompensasi pengosongan tempat sewa sebelum masa sewa berakhir, atau penyewa menyerahkan sejumlah uang diluar harga sewa pada pemilik untuk dapat memperpanjang masa sewa.

Kedua, para ulama kontemporer memasukkan sebagian praktik alKhuluw dalam wilayah hak cipta (حقوق الإبتنكار) yang diakui keabsahannya menurut hukum Islam, yaitu penguasaan seseorang terhadap sesuatu yang tidak berbentuk materi semisal hak pengarang, hak karya produk, dan hak hasil kreatifitas.

Praktik kompensasi pelepasan hak (al-Khuluw) yang masuk dalam kategori hak cipta, diantaranya adalah kasus-kasus al-Khuluw yang membuktikan bahwa pihak pemilik atau penyewa memiliki peran penting dalam ikut serta mensponsori dan membuat opini umum yang positif sehingga banyak menarik konsumen berminat pada tempatnya.

Ketiga, sebagian praktik kompensasi pelepasan hak (al-Khuluw) seperti kasus penyewa enggan membatalkan akad sewa dipertengahan masa sewa, kecuali pemilik menyerahkan sejumlah uang diluar harga sewa sebagai kompensasi bagi penyewa, menurut ulama kontemporer termasuk dalam wilayah bab pembatalan transaksi (الإقالة).

Dengan berpijak alasan tersebut, maka status hukum praktik alKhuluw ini diperbolehkan kalau mengikuti pendapat ulama Malikiyah bahwa al-iqalah adalah termasuk jual beli baru, dan tidak boleh kalau mengikuti mayoritas ulama madzhab yang menyatakan al-iqalah termasuk dalam kategori pembatalan (fasakh) yang dilarang menentukan harga diluar harga pertama.

Disamping itu, para ulama juga memasukkan praktik ini dalam wilayah jual beli manfaat (بيع منفعـة) dengan asumsi bahwa pada prinsipnya uang tersebut merupakan harga jual dari sisa waktu sewa yang ditentukan penyewa dari pemilik yang berkeinginan menarik kembali tempatnya dari penyewa. Praktik ini menurut ulama kontemporer seperti DR. Muhammad Sulaiman al-Asyqar dan DR. Muhammad Utsman Syabir diperbolehkan dan tidak bertentangan dengan dalil-dalil syar'i. 


\section{Implikasi Praktik Kompensasi Pelepasan Hak (al-Khuluw)}

Dalam realitasnya, praktik kompensasi pelepasan hak (al-Khuluw) mempunyai dampak positif dalam meningkatkan laju perekonomian di Negara-negara Islam. Di sisi lain, al-khuluw dapat menjadi sarana untuk memperluas jaringan investasi para pemilik modal yang ingin mengembangkan modal yang dimilikinya. Sehingga, semakin banyak investasi yang ditanamkan, berarti perputaran ekonomi di suatu Negara semakin positif dan dapat membuka lapangan kerja yang semakin luas.

Di samping itu, praktik sewa-menyewa apartemen/perumahan dengan cara al-khuluw dapat mengurangi beban pemerintah dalam menangani masalah pemukiman penduduk di saat terjadi lonjakan jumlah penduduk, serta dapat merangsang pemilik rumah/apartemen untuk semakin meningkatkan kualitas dan fasilitas tempat yang disewakan dalam rangka menarik minat para penyewa.

Dengan berpijak pada realitas bahwa praktik kompensasi pelepasan hak (al-Khuluw) yang berkembang di Negara-negara Islam seperti Mesir, Irak, Syiria, dan Maroko sangat berdampak positif pada perekonomian Negara, perkembangan sektor perdagangan, pemukiman, dan pertanahan. Maka selayaknya bagi Negara Islam lain seperti Indonesia juga menerapkan praktik tersebut dalam usahanya membangun perekonomian Negara. ${ }^{39}$

\section{G. Simpulan}

Dari beberapa data yang dipaparkan pada bab-bab sebelumnya, penulis bisa menarik kesimpulan sebagai berikut: 1) Bahwa praktik kompensasi pelepasan hak (al-Khuluw) baik yang berkembang pada masa klasik maupun modern dengan semua latar belakang yang melingkupinya, merupakan realitas prilaku ekonomi umat Islam yang menjadi tradisi dan tidak mungkin dapat dihindari dari kehidupan sehari-hari; 2) Fatwa-fatwa ulama klasik dan hasil ketetapan Akademi Fikih Islam (Majma' al-fiqh alIslamy) OKI beserta argumentasi-argumentasi yang dikemukakan tentang praktik kompensasi pelepasan hak (al-Khuluw), merupakan bentuk tanggung jawab ulama dalam merespon segala prilaku umat, dan merupakan rujukan terpenting untuk mengaplikasikan dan mengembangkan praktik tersebut agar tidak terjerumus dalam praktikpraktik yang dilarang agama; dan 3) Praktik kompensasi pelepasan hak (al-Khuluw) dalam sejarah perkembangan ekonomi umat Islam klasik dan modern telah terbukti mampu ikut berperan serta meningkatkan taraf

39 ibid 
hidup okonomi umat di Negara-negara Islam, dan turut membantu negaranya dalam mengatur keseimbangan struktuk ekonomi, dan stabilitas Negara seperti dalam sektor perwakafan, pertanahan, perdagangan, dan pemukiman bagi penduduk.

\section{DAFTAR PUSTAKA}

Abdullah, Amin, Prof., DR., Madzhab Jogja, Yogyakarta, ar Ruz Press, 2002. Al-Bahuty, Manshur, Kassyaf al-Qanna', Bairut, Dar al-Fikr, tt.

Al-Bujairimy, Sulaiman, Tuhfah al-Habib, Bairut, Dar al-Fikr, 1401 H/1981 M.

Al-Bukhori, Shahih al-Bukhori, Bairut, al-Maktabah al-Tsaqafiyah, tt. Al-Dardir, Ahmad, al-Syarh al-Shoghir, Bairut, Dar al-Fikr, tt.

Al-Fayyumy, Ahmad bin Muhammad, Al-Misbah al-Munir, Bairut, Dar alFikr, tt.

Al-Haitamy, Ibnu Hajar, al-Fatawa al-Kubro, Bairut, Dar al-Fikr, 1403 $\mathrm{H} / 1983 \mathrm{M}$.

Al-Kasany, Abu bakar, Bada'i al-Shana'i, Bairut, Dar al-Kutub al-Ilmiyah, tt. Al-Khin, Musthofa, Dr., Atsar al Ikhtilaf fi al Qawaid al Ushuliyyah Fi al Ikhtilaf al Fuqoha', Bairut, Muassasah al Risalah, 1417 H/1996 M.

Al-Khotib, Muhammad Ujaj, DR., Ushul al Hadits, Bairut, Dar al Fikr, 1409 $\mathrm{H} / 1989 \mathrm{M}$.

Al-Maqdisy, Abdurrahman, al-Syarh al-Kabir, Bairut, Dar al-Fikr, tt.

Al-Munawawar, Said Aqil Husin, Prof., DR., Al Qur'an Membangun Tradisi Kesalehan Hakiki, Jakarta, Ciputat Press, cet. 1, 2002.

Al-Na'im, Abdulah Ahmed, Dekonstruksi Syariah, Yogyakarta, LKIS, 1997.

Al-Syafi'I, Muhammad bin Idris, al-Um, Bairut, Dar al-Ma'rifah, tt.

Al-Salus, Ali Ahmad, DR., al Iqtishad al Islamy, Dauhah, Dar al Tsaqafah, $1418 \mathrm{H} / 1997 \mathrm{M}$.

Al-Zuhaili, Wahbah, DR., al Fiqh al Islamy Wa Adillatuhu, Bairut, Dar al Fikr, cet. IV, 1418H/1997M.

A.W. Munawwir, Kamus Munawwir, Surabaya, Pustaka Progresif, 1997.

Chapra, M. Umer, DR., Masa Depan Ilmu Ekonomi, Jakarta, Gema Imani Press, 2001.

Departemen Agama RI, Al Qur'an dan Terjemahannya, Bandung, CV. Penerbit Diponegoro, 2000.

Dewan Redaksi Ensiklopedi Islam, Ensiklopedi Islam, Jakarta, Pt. Ichtiar Baru Van Hoeve, cet. 6, 1990.

Hasan, Ibrahim Hasan, Sejarah Dan Kebudayaan Islam, Yogyakarta, Kota Kembang, 1989.

$370 \mid$ JURNAL LISAN AL-HAL 
Haurani,Albert, Sejarah Bangsa-Bangsa Muslim, cet. 1, Terj. Irfan Abu Bakar, Bandung, Mizan, 2004.

Ibnu Abidin, Hasyiyah Raddu al-Mukhtar, Bairut, Dar al-Fikr, cet. 2, 1386 $\mathrm{H} / 1966 \mathrm{M}$.

Ibnu Hanbal, Ahmad, Musnad Ibnu Hanbal, Bairut, Dar Ihya'i al-Turats al'Araby, 1415 H/1994 M.

Ibnu Najim, al-Asybah Wa al-Nadza'ir, Bairut, Dar al-Kutub al-Ilmiyah, tt. Ibrahim Anis dkk, al-Mu'jam al-Wasith, cet. 2, Bairut, Dar al-Fikr, tt.

Khollaf, Abdul Wahab, DR., Ilmu Ushul al- Fiqh, cet. 12, Beirut, Dar alQalam, 1398 H/1976 M.

Ma'luf, Luis, al-Munjid, Bairut, Dar al-Masyriq, cet. 39, 2002.

Mannan, M. Abdul, Prof., MA., PH.D, Teori dan Praktik Ekonomi Islam, Yogyakarta, PT. Dana Bhakti Prima Yasa, 1997.

Nasution, Harun, prof., DR.,Pembaharuan Dalam Islam, cet. 12, Jakarta, Bulan Bintang, 1996.

Siti Maryam dkk, Sejarah Peradaban Islam, Yogyakarta, LESFI, cet. 1.

Syabir, Muhammad Ustman, DR, al- Mu'amalat al-Maliyat al- Mu'ashirah, cet. 1, Yordania, Dar al-Nafa'is, 1416 H/1996 M.

Ulaisy, Fathu al-'Aly al-Malik, Mesir, Syirkah Maktabah, 1378 H/1985 M.

Yasid, Abu, DR., LLM, Islam Akomodatif, Yogyakarta, LKIS, 2004.

Yatim, Drs. Badri, MA, Sejarah Peradaban Islam, cet. 6, Jakarta, PT. Raja Grafindo Persada, 1997.

Zahrah, Muhammad Abu, Ushul al Fiqh, Bairut, Dar al Fikr,tt. 
"Kompensasi Pelepasan Hak"

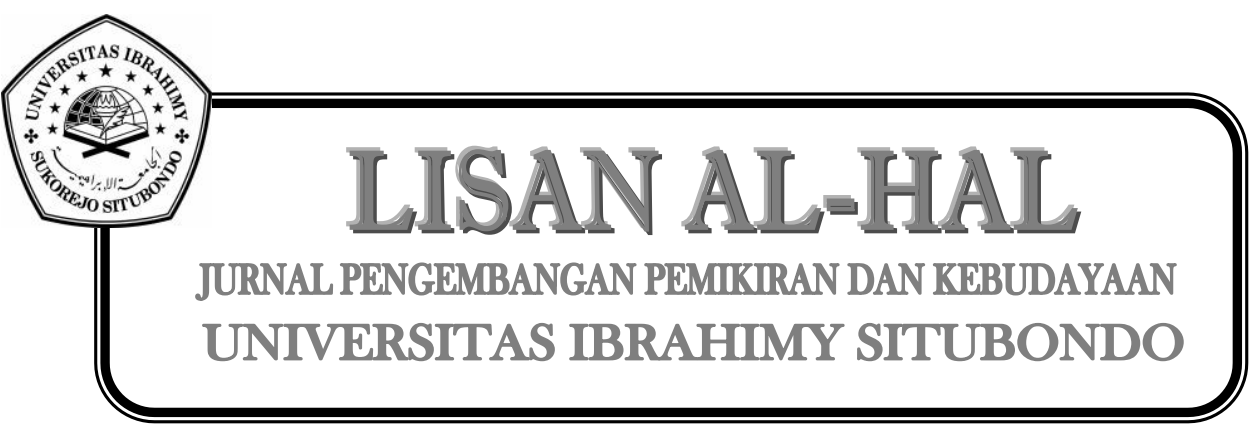

372 JURNAL LISAN AL-HAL 